\title{
Determinants of firm performance in a less innovative transition system: exploring Vietnamese longitudinal data
}

\section{Quan Hoang Vuong}

Centre Emile Bernheim, Université Libre de Bruxelles, 50 Ave. F.D. Roosevelt, Brussels B-1050, Belgium and FPT University School of Business, VAS Building C, My Dinh 1, Tu Liem District, Hanoi, Vietnam Email: qvuong@ulb.ac.be

\begin{abstract}
This study investigates a longitudinal financial data set from 37 companies listed on Vietnamese stock market, during 2004-2013 - a tumultuous transition period, which show major weaknesses of a less innovative system in a resource-constrained setting. The significance of relationships between operational scales, sources of finance and firms' performance reflects the nature of a business environment in transition and lower innovativeness. First, when an innovation strategy is absent, the obsession and over-emphasis of capital resources become overwhelming and persistent. Second, firm size shows mixed contribution to performance. Third, the study has found negative effects of sales and growth rate to ROE and profit margins, raising a question on the combined 'lower innovativeness' and 'tumultuous transition' setting. Finally, the effect of time is significant on key factors. These insights potentially lead to an advocacy of restructuring the corporate sector regarding usage of resources, market orientation and technological innovation for revamping competitiveness.
\end{abstract}

Keywords: economic system in transition; firm performance; innovation; longitudinal data; operational scales; Vietnam.

Reference to this paper should be made as follows: Vuong, Q.H. (2016) 'Determinants of firm performance in a less innovative transition system: exploring Vietnamese longitudinal data', Int. J. Transitions and Innovation Systems, Vol. 5, No. 1, pp.20-45.

Biographical notes: Quan Hoang Vuong has served as a Senior Researcher at Centre Emile Bernheim, Universite Libre de Bruxelles since 2003, and FPT University School of Business since 2016. He was awarded the Vietnamese National Book Prize (2007) and National Journalism Prize (2010). His research articles have been published in such journals as: Vietnam Journal of Mathematics, VNU J. of Science, Int. J. Transitions and Innovation Systems, Int. J. Human Resources Development and Management, Management Research Review, Int. J. Intercultural Relations, SpringerPlus, J. Innovation and Entrepreneurship... and in book chapters with such publishers as Palgrave Macmillan, Praeger, Routledge, World Scientific. He currently advises Hanoi 
Stock Exchange on technical matters relating to equity and bond indexes. $\mathrm{He}$ also manages the research philanthrophy Quang-Vu-Hung Hoi Foundation, founded by Mr. Vu Quang Hoi (Bitexco Group's Chairman).

\section{Introduction}

\subsection{Background}

Vietnam launched its extensive economic reforms, formally known as Doi Moi, 30 years ago, on the verge of a devastating economic crisis. Its GDP per capita declined to US\$97 in 1989 whereas External Debt/GDP reached 330\% (Vuong, 2010). The economy languished and became one of the poorest in the world. But the miraculous growth has saved the nation from declining further. Today, with a 92-million population, Vietnam's GDP is over US\$210 billion, resulting in a GDP per capita of $>$ US $\$ 2,300$, or $\sim 5.3$ times of the 1986's figure (Pincus, 2015; GSO, 2016; SBV, 2016). Doi Moi has enabled the marketisation/internationalisation of the economy, bringing about the fruits of market, thanks to the flourishing of a thriving business sector, Vietnam's growth engine.

But the recent 'transition turmoil' period has exposed a number of critical issues with the growth engine. Although 94,700 new enterprises were created in 2015, registering an additional capital of US\$27.3 billion - according to Vietnam's Ministry of Planning and Investment $-80,900$ enterprises dissolved or temporarily closed in the same year, $50 \%$ higher than that of 2011, see Figure 1 (MPI, 2016). Numerous reasons are cited but the striking one is that the corporate sector faces issues of lacking significant innovative capacity, relatively lower competitiveness and lower value-added capacity. Reliance on resources, especially financial one, leads to diminishing return and heavier indebtedness, leaving little room for reinvesting in innovating technologies and business management.

Figure 1 Newly formed versus stopped businesses (see online version for colours)

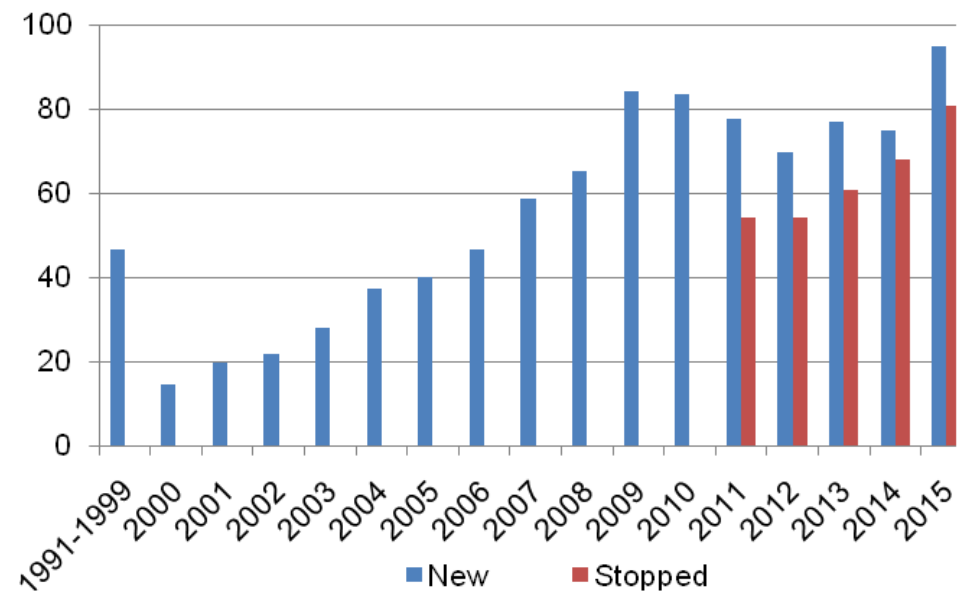

Note: Unit: $1,000 /$ year

Source: Ministry of Planning and Investment 
In many aspects, Vietnam represents a transition economic system, embedded with emerging market characteristics, which has sparked earnest academic interests. Before the 2008-2010 financial crisis started out, the country's fast-growing economy had already seen a 2-digit inflation raging, following years of overinvestment and sky-rocketing speculative and real estate asset prices (Pham and Riedel, 2012; Vuong, 2014). Domestic firms, both privately held and state-owned, tried all ways possible to acquire financial and land resources to expand, and also speculate. Very few made a serious question about why they do what they do, and for what purposes. Overwhelming goals of increasing scales and scopes have generally obscured both raison d'être of a firm and relevance/efficiency of business strategies and practices, and not unusually even become contradictory to its publicised statements of vision and/or business philosophies. This tendency appears to have risen amid tumultuous periods of time when profit margins (PMs) declined due to increasingly fierce competition and lower competitiveness as innovativeness is not of primary concern (Vuong and Napier, 2014). There is an increasingly popular view that Vietnam's Doi Moi II - that would help Vietnam mitigate the risk of the so-called 'middle-income trap' - will have to deal with managing and financing the future innovation capacity.

\subsection{Problem statement}

The situation poses a critical question on the problem of financing sustained growth, which implies financing innovations within the business sector. The problem has further been exacerbated due to wild fluctuations of lending interest rates in Vietnam (see Figure 2) necessitated by monetary policy measure while dealing with high inflation subperiods. Therefore, the problem can also be asked: How do operational efficiency/scales and sources of finance affect performances and financial efficiency of Vietnamese firms? The next discussion tries to justify this crucial question, and to layout an appropriate, albeit brief, literature review in the next section.

Figure 2 Vietnam vs. US policy interest rates, 2000-2015 (see online version for colours)

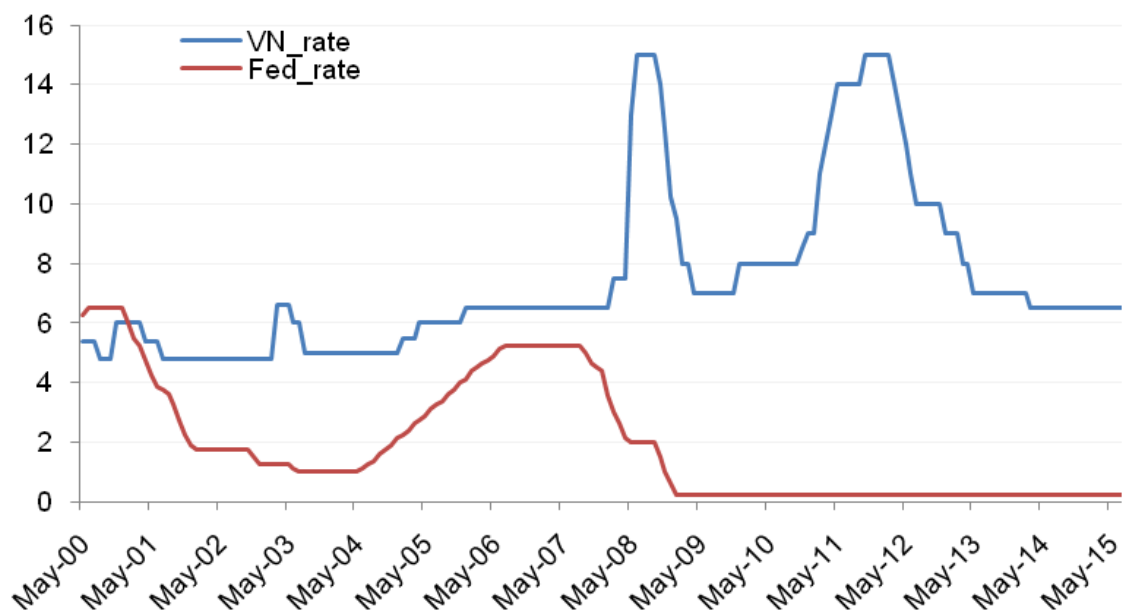

Note: Unit: \% p.a.

Source: Vuong \& Associates 
This paper investigates the relationships between business efficiency (operational scales included), sources of finance and corporate financial performance, with a view toward enterprises' financial slack for future innovative practices. In this consideration, the Vietnamese socio-cultural and politico-economic context has made the first two groups of factors the predictor variables for firm performance. Thus, we follow the logic to implement subsequent econometric analysis, using a Vietnamese longitudinal data set.

\section{Literature review}

The following literature elaborates on points briefly discussed in the problem statement for:

1 justifying the aspects of study's consideration

2 building some necessary connections for examining

3 guiding the hypothesis testing exercises and the results provided toward the end.

\subsection{A brief review of the extant world literature}

Early thinking on relevance of choices of finance led to Modigliani and Miller's (1958) theorem on capital structure, which has inspired a great number of researchers to make academic efforts in studying various issues related to capital structure. In light of this, Jensen and Meckling's (1976) work on relationship between investment and financing decision started a new wave of research on the relationship between capital structure and corporate performance, and optimal capital structure, such as Beard and Dess (1981), Ofek (1993), Rajan and Zingales (1995), Jordan et al. (1998), Zeitun and Tian (2007) and Ahmad et al. (2012). Several excellent review and meta-analysis papers, e.g., Capon et al. (1990) and Inkinen (2015), show that there could hardly be a consensus among economists as empirical results have led to different conclusions of roles of debt, equity and hybrid finances, depending on periods, locations, type of economy, etc.

Researchers around the world rely on econometric techniques and available data to examine the relationship between capital structure and corporate performance, for instance, Harris and Raviv (1991), Krishnan and Moyer (1997), Gleason et al. (2000), Abor (2005), Zeitun and Tian (2007), and Ahmad et al. (2012). These regression results, on the one hand, provide empirical evidence for one of the most controversial topics in the business academic literature. On the other hand, purely technical approaches may miss the point: corporate performance is also affected by elusive variables such as innovation strategy, and socioeconomic and cultural settings. Barton \& Gordon (1987) even point out that extensive theoretical and empirical studies have failed not just to determine which factors influence capital structure, but also to confirm whether capital structure really affects the value of firms.

But recently, renewed research efforts have enhanced the literature with new evidence from both developed and developing countries. To study that relationship, Zeitun and Tian (2007) use panel data sample of 167 Jordanian companies during 1989-2003, using Tobin's Q, market value of equity to the book value of equity (MBVR), price-to-earnings per share $(\mathrm{P} / \mathrm{E})$, and market value of equity and book value of liabilities divided by book value of equity (MBVE) to measure corporate market performance while return on equity (ROE), return on assets (ROA), and earnings before interest and tax plus depreciation to 
total assets (PROF) serve as accounting/financial performance. Their independent variables (IV) are various leverage measures:

1 total debt/total assets (TDTA)

2 total debt/total equity (TDTE)

3 long-term debt/total assets (LTDTA)

4 short-term debt/total assets (STDTA)

5 total debt/total capital (TDTC), growth of sales, size of assets or sales, STDVCF (standard deviation of cash flow - net income plus depreciation) for the last three years, tangibility (Fixed Assets/Total Assets).

Their empirical results suggest that "ROA and Tobin's Q are the most powerful measures of performance" and "higher level of leverage lead to lower ROA" (p.49). In addition, three proxies for capital structure - LTDTA, STDTA and TDTE - are found to be negatively related to profitability.

Harris and Raviv (1991) show that, firms may have more debt in their capital structure than they should because of underestimation of bankruptcy costs of liquidation or reorganisation, or the aligned interest of both managers and shareholders. Krishnan and Moyer (1997) confirm negative and significant impact of financial leverage on ROE. Gleason et al. (2000) provide evidence that firm capital structure has a negative and significant impact on ROA, growth in sales, and pre-tax income. Interestingly, they also point to the fact that capital structures differ by the socio-cultural settings.

Barclay and Smith (1995) find that large firms and firms with low growth rates prefer to issue long-term debt (LTD), while Stohs and Mauer (1996) suggest that larger and less risky firms usually make greater use of LTD. Schiantarelli and Sembenelli (1999) find a positive relationship between initial debt maturity and medium-term performance in Italy and UK. Chakravarthy (1986) suggests that corporate financial performance can also be measured by profit maximisation - maximising profit on assets, and maximising shareholders' benefits. In addition, Hoffer and Sandberg (1987) consider growth in sales and growth in market share operational performance which later on defines financial results of corporations.

ROA, ROE, and return on investment (ROI) are the most common proxies for corporate performance since the measures have been employed by Demsetz and Lehn (1985), Gorton and Rosen (1995), Mehran (1995), and Ang et al. (2000). Related measures include earnings per share (EPS), Tobin's Q and market value of equity to book value of equity (MBVR). Prahalathan and Ranjani (2011) examine the impact of capital structure choice on corporate performance of 65 listed firms for the period 2003-2007, in Sri Lanka. The author employed multiple regression analysis to estimate the relationship between financial performance - represented by gross PM, ROA, and ROE - and leverage ratios of short-term debt to total assets (STDTA), LTD to total debt, total debt to total assets, and firm size. They find that capital structure to have statistically significant negative impact on gross PM, but not ROA and ROI.

San and Heng (2011) are interested in the impact of capital structure on corporate performance in a single industry, thus investigate 49 listed Malaysian firms during 2005-2008. While dividing firms into big, medium and small based on paid-up capital, the authors propose such dependent variables (DV) representing performance as return on capital (ROC), ROE, ROA, EPS, operating margin, and net margin - and such IV as: 
long-term debt/capital (LDC), debt/capital (DC), debt/assets (DA), debt/equity market value (DEMV), debt/common equity (DCE), and long-term debt/common equity (LDCE). OLS estimations show that only ROC and EPS have significant relationship with capital structure in big firms, operating margin in medium firms, and EPS in small firms. In addition, significant IV are DEMV, LDC, DC of big firms; LDCE of medium firms; and, DC of small firms. In addition, Ahmad et al. (2012) also investigate the capital structure-corporate performance relationship in Malaysian firms, using the 20052010 data set containing 58 firms, analysing the impact of STD, LTD on ROA, ROE. Their findings are different to those reported by San and Heng (2011), suggesting significant relationship between ROA and STD and LTD.

Salteh et al. (2012) study the relationship between capital structure and corporate performance in 28 Iranian listed companies in vehicles and parts manufacturing sector, from 2005 to 2009. Multi regression analysis is also employed to estimate the impact of leverage ratios - including SDTA, long-term debt to total assets (LDTA), total debt to total assets (TDTA), and total debt to total equity (TDTE) - on corporate financial performance represented by ROE, ROA, EPS, market value of equity to book value of equity (MBVR), and the Tobin's Q. Salteh et al. (2012) provide empirical results suggesting that

1 EPS and ROA are negatively related to capital structure

2 ROE and Tobin's Q are positively related to TDTE

3 MBVR is statistically significant related to SDTA.

While (1) is in line with Zeitun and Tian (2007), Rajan and Zingales (1995), and Abor (2005), it is contrary to the works of Champion (1999), Ghosh et al. (2000), Hadlock and James (2002), and Berger and di Patti (2006) which show a positive relationship. More recent studies such as Alipour et al. (2015), Chang et al. (2015) report consistent results compared to the above discussion.

While many study the impacts of capital structure on corporate performance, for instance, Salteh et al. (2012), Ahmad et al. (2012), San and Heng (2011), Prahalathan and Ranjani (2011), and Zeitun and Tian (2007). Jordan et al. (1998), in a reverse approach, examine factors that explain corporate debt levels. While looking at capital structure through traditional proxies, i.e., leverage and gearing, the work of Jordan et al. (1998) also makes difference by its focus on SMEs, not large and public firms. Regression results suggest that financial and strategic factors, including turnover, profit, and innovation strategy, are necessary to explain corporate debt levels.

O'Brien (2003) investigates the relationship between innovation-based competitiveness strategy and capital structure, and corporate performance, employing a dataset of 16,358 firms that have filed reports to the US Securities and Exchange Commission and been listed for more than one year during 1980-1999. While capital structure is represented by a leverage measure (book value of debt/total market value of firm) and M/B (market value of firm/book value of total assets), IV include innovation (proxy for relative R\&D intensity of firm), R\&D intensity (firm-level expenditures on $\mathrm{R} \& \mathrm{D} /$ Sales), advertising intensity (expenditures on advertising/sales), size (book value of total assets), profitability (ROA), capital intensity (book value of total assets/sales), and tangible assets/total assets ratio. This study performs OLS regressions with lagged DV as predictor variables. The results suggest that there are intangible factors that determine 
both corporate capital structure and performance, such as innovation-based competitive strategy.

Empirical results provided by Ozkan (2001) while surveying 390 UK firms in during 1984-1996 suggest that firms have the so-called 'target borrowing ratios', and tend to adjust to their targets quite fast. In other words, moving away from the desirable level of debt could be costly. Also, the author provides evidence on positive impact of size, and negative effects of growth opportunities, liquidity, profitability, and non-debt tax shields on the borrowing levels. Harvey et al. (2004) investigate the effect of capital structure, especially the use of internationally syndicated loans, on firms value creation, with significant results. The authors show that equity holders value compliance with 'monitored covenants' in presence of overinvestment, particularly in emerging markets.

From operational perspectives, Hovakimian et al. (2004) provide interesting insights:

a high market-to-book firms have good growth opportunities and, therefore, have low target debt ratios

b the importance of stock returns in studies of corporate financing choices is unrelated to target leverage and is likely to be due to market timing behaviour

c profitability has no effect on target leverage.

So, their evidence supports the hypothesis that firms have target capital structures. Also, Opler and Titman (1994) provide evidence that heavily indebted firms tend to lose market share to those conservatively financed rivals when market conditions worsen. Highly leveraged firms also suffer from equity value decline. Financial distress costs adversely affect firms' financial performance, especially those with highly specialised products and using debts to finance R\&D activities. Use of moderate debt can be productive, but high indebtedness potentially leads to market underperformance. Empirical results using international data from a research by Rajan and Zingales (1995) also show influence of some key factors to capital structure: tangibility $(+)$, market-to-book ratio (-), firm size $(+)$, and profitability $(-)$, with varying degrees depending on level of concentration and country. The study focuses on developed market economies. Margaritis and Psillaki (2010) results are confirmatory of those reported by Rajan and Zingales (1995) and Huang and Song (2006) for non-G7 enterprises.

Also, Gallo and Vilaseca (1996) analyse issues of capital structure of family firms, behaviour towards investments and risk, and dividend policy and reach conclusions that those with stronger market-share positions tend to have low debt/equity levels. Yet, having leading market-share positions does not automatically mean superior financial performance over followers. While doing research of 986 African firms during 1999-2008, using GMM/SUR methods, Lemma and Negash (2013) report that probability of bankruptcy, agency and transaction costs, tax issues and information asymmetry, access to finance and market timing, but not firms' profitability, are significant factors influencing the choice of capital structure. Finally, Coleman and Robb's (2011) multivariate analysis shows that new technology enterprises, especially fast-growing ones, are focused on size of capital more than others, preferring internal sources to maintain control. However, firms do use both equity and debt finances. Availability of finance does not appear to be a major issue for technology-based firms with high growth and strong competitive advantages (Klingler-Vidra, 2014; Inkinen, 2015; Pincus, 2015). 
Regarding the issue of innovation capacity, Hall (1992) discussion about debt as unsuitable option for financing R\&D, and Brown et al. (2009) point out that American firms finance their innovations from volatile sources such as cash flow and stock issues but only cash flow and external equity are found to be significant, and only among younger firms. Lower cash flow reduces R\&D for constrained young firms. Their evidence builds a natural connection between financials, innovation and growth, highly relevant to the aforementioned problem statement. For young firms, R\&D-to-Assets ratio ranges from 12 to $16 \%$, while for mature firms, this runs from $6 \%$ to $9 \%$. In addition, public equity finance can be an important source for financing innovation, in similar way to how Bottazzi and Da Rin (2002) see the role of venture capital in Europe for financing credit-constrained innovative companies. Bottazzi and Da Rin (2002) show that sales growth has influence on firms' operational scales and the potential venture-capital financing prospects for young firms seeking finance, i.e., their capital structure; the view is in part supported by evidence from developed economies (e.g., Bernstein, 2015; Inkinen, 2015; Pahnke et al., 2015) as well as from developing economies (Iturrioz et al., 2015; Vuong et al., 2016a).

And from another angle, O'Brien (2003) provides evidence that the choices of debt or equity financing depend on business leaders' consideration of firm strategy, with maintaining financial slack being a crucial factor in strategic decisions regarding future capacity for taking up innovative opportunities. One of O'Brien's (2003) salient insight that is highly relevant to this study is: "A highly levered firm with factories geared towards large-scale, low-cost output would be faced with quite a challenge if it decided that it needed to become an innovator". In addition, Cosh et al. (2009) suggest although firms may be able to secure their required finance from one of different sources available, external finance is rarely available in the form that they prefer. Thus only those with higher capex/profits and strong growth objectives are likely to seek external finance. As "firms prefer to finance new projects internally prior to seeking external capital" - according to Cosh et al. (2009) - operational efficiency clearly affects the choices of not only capital structure but also the tendency of pursing innovation efforts (Pahnke et al., 2015; Tran and Santarelli, 2014; Vuong et al., 2016b).

Last but not least, there has been increasing evidence showing that firms with greater levels of financial slack are more likely to respond to poor innovative performance using greater vehicle diversification, and new sourcing vehicles (Inkinen, 2015; Lungeanu et al., 2015).

\subsection{Some relevant insights from emerging markets and Vietnam}

Regarding transition economies, Bevan et al. (1999) study the determinants of enterprise performance, where the need of restructuring makes substantial capital investment expenditure a relatively important condition. The author discuss that firms in these economies are likely to experience acute financial constraints, leading banks to play a more prominent role. But in general, leverage ratios appear to have been lower in European transition economies: $32 \%$ and $41 \%$ for Hungary and Poland respectively. The figure is $\sim 66 \%$ for G7 non-financial firms according to Rajan and Zingales (1995). Also, before the so-called 'transition turmoil' period 2007-2013, Vietnamese capital market's anomalous events have been reported in previous studies, such as Farber and Vuong (2004) and Vuong (2010). 
Most Vietnamese enterprises can be classified as 'constrained and young' according the standards set by Brown et al. (2009) and Bottazzi and Da Rin (2002). Their problem of capital constraints has been well known and documented such as in Thanh et al. (2011), Vuong (2014), WB (2014) and ADB (2014, 2015).

With respect to capital structure issues, Phung and Le (2013) study a smaller data set of firms listed on Ho Chi Minh Stock Exchange during the period 2008-2011, providing some evidence of negative impact of foreign ownership on firm performance, and positive impact on capital structure. They offer an explanation of foreign investors' limited ability to monitor Vietnamese firms' corporate governance practices. As foreign investors may suffer from the problems of information asymmetry, they tend to advocate higher debt finance for mitigating agency problem.

As for young firms, Tran and Santarelli (2014) investigate the effect of capital constraints on the performance of entrepreneurial firms, using a panel of 1,721 firms in a 4-year time period, reporting evidence that entrepreneurial firms that face capital constraints tend to perform substantially better, roughly $4.9 \%$ above the norm. Also, Vuong (2014) discusses the deeply-rooted issues of the political economy that have lead to firms' choices of debt versus equity finance. Although access to bank loans have for a long time been an overwhelming issue to the majority of smaller firms, larger companies especially state-run firms are still able to borrow, and in some cases, staggering amounts of money, crowding out smaller private SMEs. At some points, abundance of resources available to well established firms has even led to the problem of 'resource curse' and 'destructive creation' whereby resource-rich firms create subsidiaries to take on speculative assets, and employs their advantage of size to borrow more (Vuong and Napier, 2014).

\section{Research questions and method of data analysis}

\subsection{Research questions}

Our review of related academic literature helps gain some understanding. First, there can be two ways to look at the relationships between factors constituting the so-called capital structure and firms' performance, in which the view of 'target capital structure' appears to be more suitable to developed market, while the view of capital structure and related operational dimensions (sales, growth, size) affecting performance tends to be more appropriate for developing economies. Second, the plethora and rising complexity of IV used in econometric analyses do not solve the issue of disagreement among various empirical results reported: signs of coefficients, magnitudes of influence, relevant IVs, and so on. There is also no evidence that more complex techniques would better explain the relationship, especially in less developed markets. Third, the longitudinal data analysis becomes more insightful and popular, although it cannot be guaranteed that well known models and reported results in academic literature would automatically become applicable in a new dataset.

The above points lead to the following key research question, which will be addressed during this study:

"How do operational efficiency/scales and sources of finance affect performance and financial efficiency of Vietnamese firms?" 
As this question is broad, some aspects of it will be presented following the examinations of the data set. The data set itself is described in the next subsection.

\subsection{The data set and method of analysis}

\subsubsection{The data set}

The dataset contains information extracted from financial reports of 37 listed companies in Vietnam, for the period 2004-2013. The factors enter into subsequent analysis include: 'STD' (short-term debt/total asset); 'LTD' (long-term debt/total assets); 'SIZE'(natural logarithm of total assets); 'SALES'(natural logarithm of Sales); 'SIG' (growth rate of 'SIZE'); 'SAG' (growth rate of 'SALES'); 'ROE'; and 'PM' (net PMs/sales). Graphs presented in Figure 3 (and Appendix 1) provide a visual check on possible pairwise relationships between some of the variables in consideration.

Figure 3 Observation of possible relationships between pairs of variables

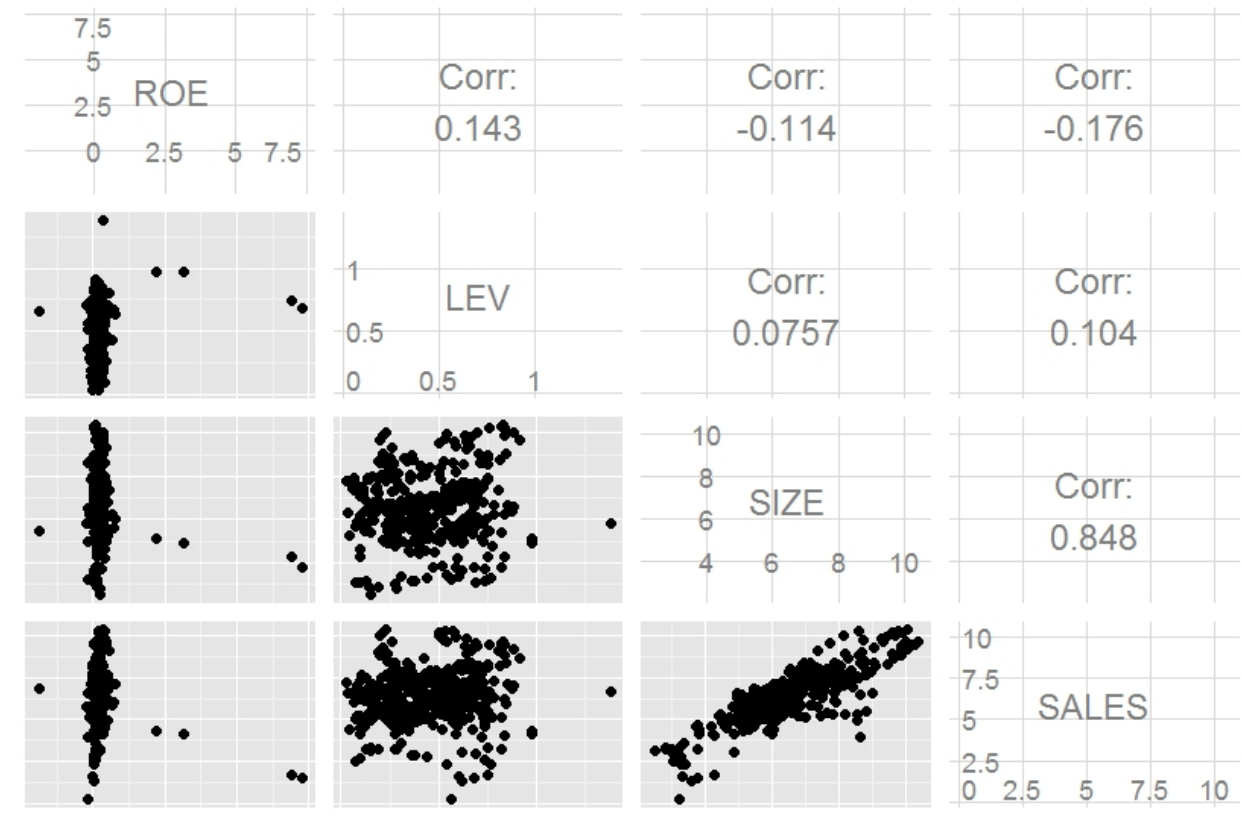

The data set used for this study is also checked for Pearson's pairwise correlation coefficients. One example is the null hypothesis that the correlation between ROE and SALES is $0\left(H_{0}\right)$. Performing this test using R, assuming that the population correlation is 0 , the result suggests that to expect a correlation coefficient of -0.176 , the chance is really slim, about $1 / 1500(\mathrm{t}=-3.4299, \mathrm{df}=368, \mathrm{p}$-value $=0.00067)$. As this is highly unlikely, $H_{0}$ is rejected; that means corr(ROE,SALES) is significant.

Next, Table 1 provides for basic statistics and Pearson's correlation coefficients, rounded to 2-digit decimal - thus, $\operatorname{corr}(S O E, S A L E S)$ is reported as -0.18 - each with a corresponding level of significance. 
Table 1 Descriptive statistics and Pearson correlation coefficient

\begin{tabular}{lcccccccccc}
\hline & Mean & S.D. & Min. & Max. & ROE & PM & STD & LTD & LEV & SIZE \\
\hline ROE & 0.21 & 0.57 & -1.87 & 7.28 & & & & & & \\
PM & 0.23 & 1.75 & -6.01 & 24.16 & $0.89^{*}$ & & & & & \\
STD & 0.36 & 0.22 & 0.00 & 2.44 & $0.23^{*}$ & 0.08 & & & & \\
LTD & 0.09 & 0.12 & 0.00 & 0.57 & -0.05 & -0.03 & -0.07 & & & \\
LEV & & & & & $0.14^{* *}$ & 0.06 & $0.76^{*}$ & $0.46^{*}$ & & \\
SIZE & 6.52 & 1.61 & 2.51 & 7.86 & $-0.11^{* *}$ & $-0.10^{* * *}$ & -0.08 & $0.25^{*}$ & 0.08 & \\
SALES & 6.39 & 6.48 & 0.26 & 10.34 & $-0.18^{*}$ & -0.19 & 0.05 & 0.04 & $0.10^{* * *}$ & $0.85^{*}$ \\
\hline
\end{tabular}

Notes: $* \mathrm{p}<0.01 ; * * \mathrm{p}<0.05 ; * * * \mathrm{p}<0.10 ; \mathrm{n}=370$. Size: 37 listed firms. Data period: 2004-2013.

\subsubsection{The method of analysis}

For this type of research question, it is plausible to employ longitudinal data analysis especially when the data set involves both time-series and cross-sectional variables, reflecting the evolution of the same group of entities/individuals over the recent years. This study uses the language of Frees (2004) where the terms 'longitudinal data' and 'panel data' are used interchangeably. Particularly, the term 'longitudinal data' is preferred for this particular set of data (with $n=37, T=10$ ) and firms are examined longitudinally.

The data sample will be examined using several specifications of pooled OLS, fixed-effects (FEs) and random-effects (REs) models. During the estimating process, some variants of these three approaches are also explored such as models with lagged DV or with time-specific effects. For technical details on determining GLS estimator and further MLE computations, see Hsiao (2003, pp.35-41), Frees (2004, Chapter 3), and Baltagi (2005, pp.14-21). Model specifications, statistical properties of independent/dependent variables and conditions for estimations are provided in Appendix A2.

\section{Empirical results}

Empirical results that are reported in Section 4 are obtained from actual estimation using the statistical package $R$ (release 3.0.2). The data set has $\mathrm{n}=37, \mathrm{~T}=10, \mathrm{~N}=370$.

First, the results of estimating three models Pooled OLS (M1); and, FE vs. RE models are reported in Table 2; with DV being ROE and IV being STD, LTD, SIZE, and SALES.

The LM Breusch-Pagan test reports a large $\chi^{2}$-statistic numerical value of 23.64 $(\mathrm{df}=1)$, and $\mathrm{p}<0.0001\left(\mathrm{p}\right.$-value $\left.=1.16 \times 10^{-06}\right)$. Since the null hypothesis of this B-P test stipulates that there is $N O$ evidence of significant differences across entities/individuals (that is variances across individuals are zeros), the test statistic rejects $H_{0}$ [Baltagi, (2005), pp.59-61]. Therefore, although most estimated coefficients are significant at conventional levels, the pooled OLS specification is not a good choice for modelling this particular data set. 
Table 2 FE, RE and Pooled OLS estimations

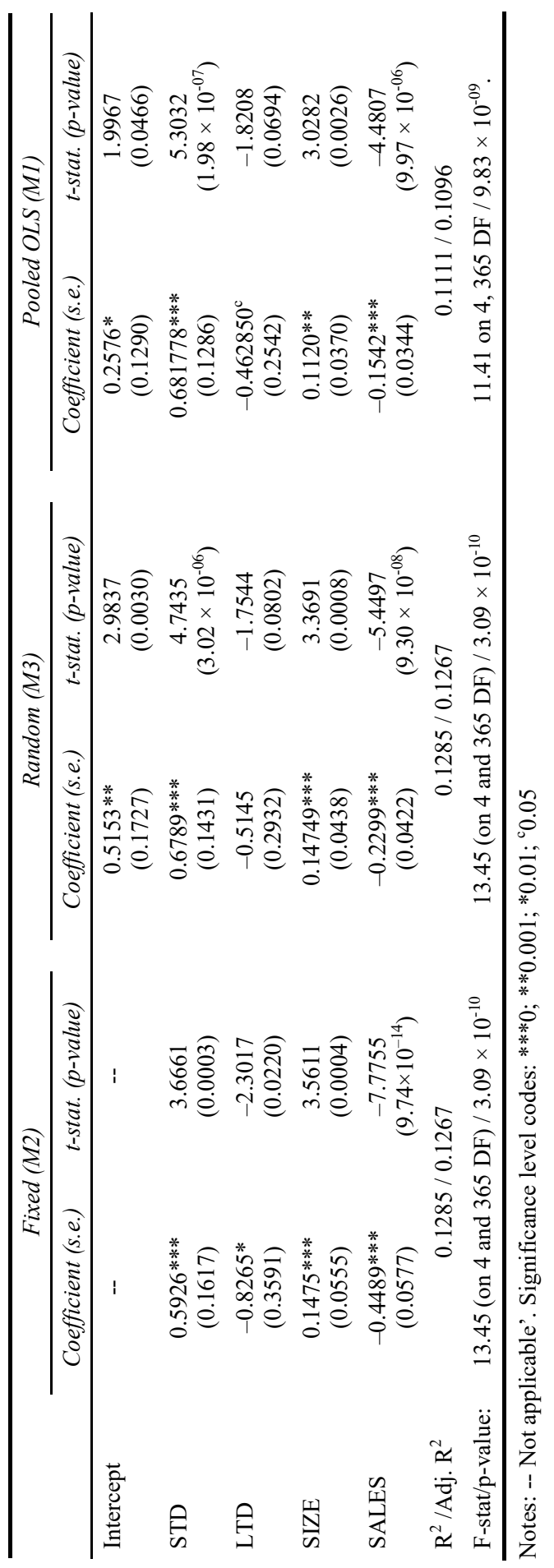


Performing the LM Breusch-Godfrey/Wooldridge test yields a $\chi^{2}$-statistic value of 95.69 , $\mathrm{df}=10, \mathrm{p}$-value $=3.95 \times 10^{-167}$, which favour FEs model choice - according to Baltagi (2005: p. 95). In addition, the Hausman test for this specification of predictor variables, between FE and RE models, yields a large $\chi^{2}$-statistic numerical value of $37.29(\mathrm{df}=4$, $\mathrm{p}$-value $=1.57 \times 10^{-07}$ ), leading to the preference of the FE model.

On the time-fixed effects - that is, only significant time-effects are reported estimation results are provided in Table 3.

Table 3 Estimation of time-fixed effects model

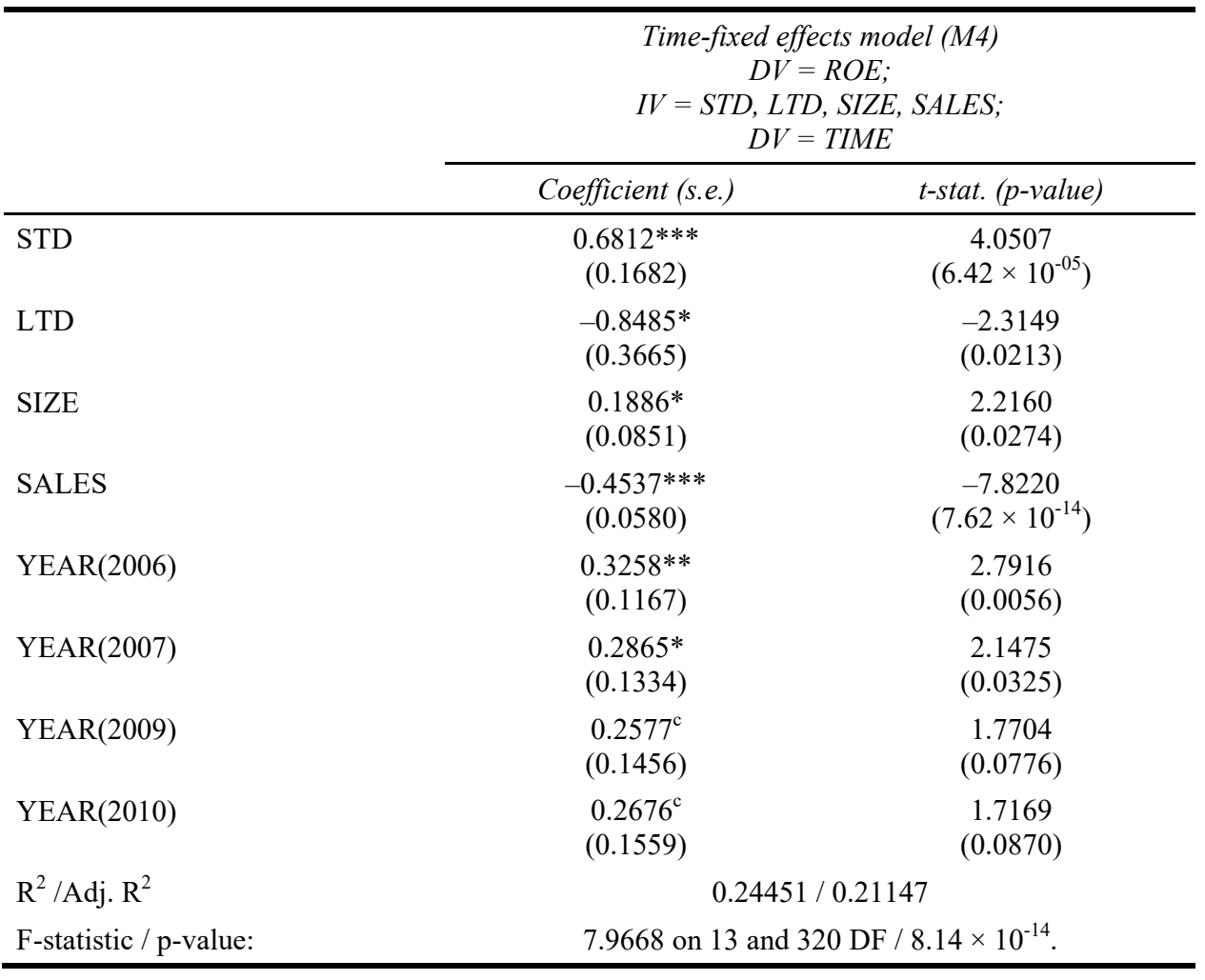

Notes: Signif. codes: $* * * 0 ; * * 0.001 ; * 0.01 ;{ }^{\mathrm{c}} 0.05$

Also the F-test for individual effects indicates that with $\mathrm{F}=1.567\left(\mathrm{df}_{1}=9, \mathrm{df}_{2}=320\right)$. Although the corresponding p-value (0.12) shows statistical insignificance of the overall specification - in which case we may say there is no need for use of the time-fixed effects to model the data set - the insights gained from significant time-effects for the two 2-year periods (2006-2007 and 2009-2010) are interesting and noteworthy (see Section 5).

Next, Table 4 reports statistics obtained from estimations of FE and RE models M5-7, using SIZE/SIZE GROWTH (SIG), and ASSET GROWTH (SAG).

Both Breusch-Pagan t-test for the first specification - for which $\mathrm{BP}=13.75, \mathrm{df}=4$, $\mathrm{p}$ value $=0.0081-$ and LM Breusch-Godfrey/Wooldridge test for serial correlation - where $\chi^{2}$-statistic $=77.68, \mathrm{df}=9, \mathrm{p}$-value $=4.659 \times 10^{-13}-$ suggest the use of FE model M5. In addition, Hausman test with $\chi^{2}$-statistic $=75.56, \mathrm{df}=4, \mathrm{p}$-value $=1.52 \times 10^{-15}$ advocates the use of FE in M5 is superior than the RE model of M6. 
Table 4 Estimated coefficients and test statistics for M5-7

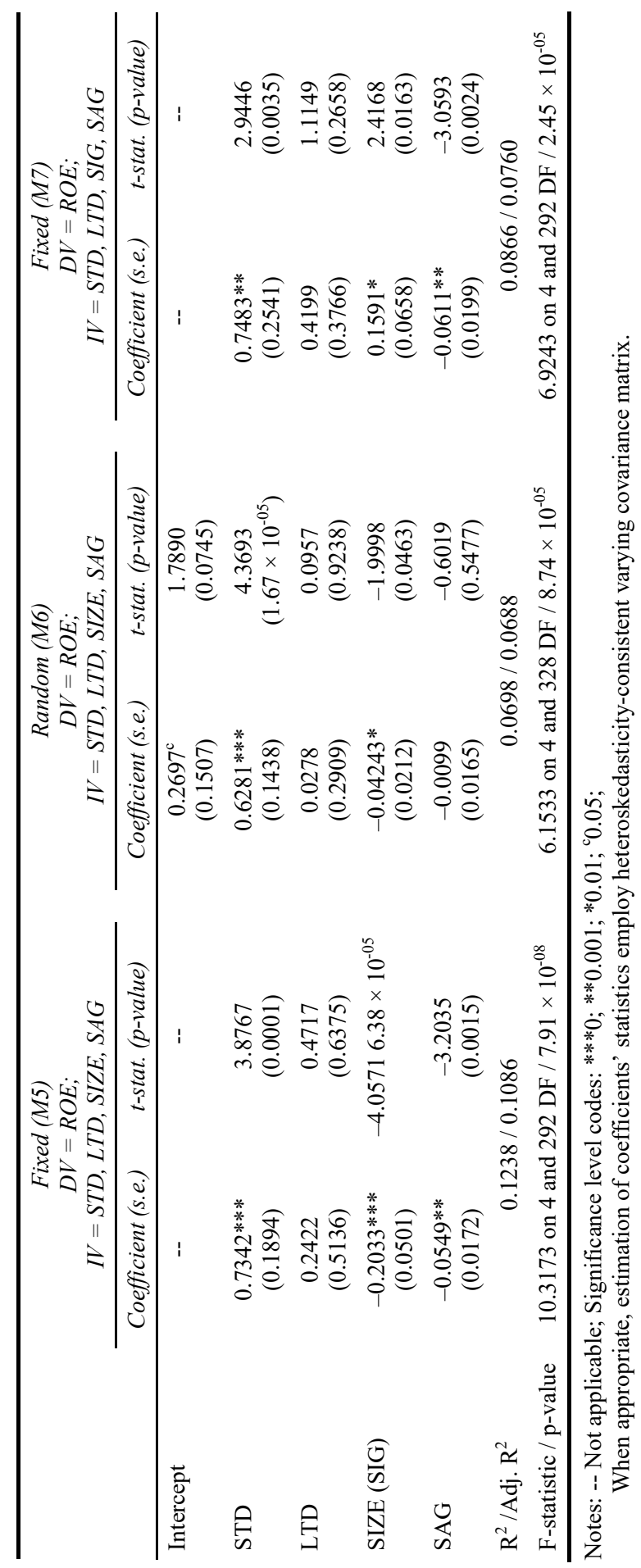


Table 5 Estimation results for FE and RE models, using DV PM

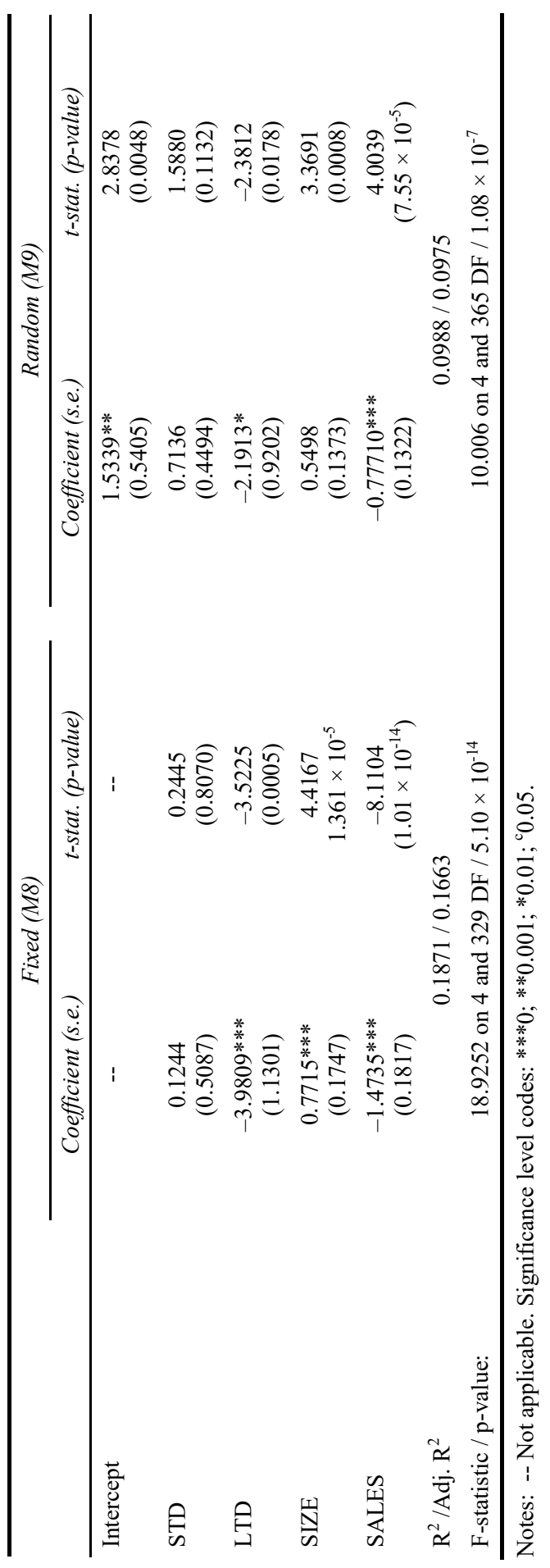




\subsection{PM instead of ROE}

In the last estimations that follow, the DV is now PM, instead of ROE as in preceding specifications (see Table 5). The data set has $\mathrm{n}=37, \mathrm{~T}=10, \mathrm{~N}=370$. The general specification is: $\mathrm{DV}=\mathrm{PM}$; IV $=\mathrm{STD}$, LTD, SIZE, SALES.

The result obtained from the Hausman test, with $\chi^{2}$-statistic value $=37.91$, df $=4$, $\mathrm{p}$-value $=1.17 \times 10^{-07}$, suggests the use of the FE model - the above-mentioned M $8-$ is appropriate.

\section{Insights and discussions}

First, the obsession of capital resources is strong in the Vietnamese emerging market, following years of harsh economic realities and shortage of finance. This has a deeplyrooted cultural reason as a long history, older people teach younger generations that: "Trade talent is no match with abundance of capital". But so far there has been virtually no reported evidence on influence of capital availability to creative performance and possibilities of technological innovation in the emerging economy of Vietnam. More recent evidence even sees this issue within the entrepreneurial firms sector, where innovation and creativity are supposed to assume a central role in improving startups' competitiveness (Vuong et al., 2016b).

We can realise that STD has constantly been the single most important factor, reflecting the long-standing issue of shortage of term financing in the emerging market economy of Vietnam, although listed firms in the dataset belong to upper-stratum and better-performing ones, compared to the society at large. For all specifications that model the response variable of ROE, STD coefficients are found positively and strongly related to firms' performance; while LTD is mostly insignificant or weakly significant, bearing negative sign (M2, M4). With DV being PM, LTD suddenly becomes very influential, with strong significance, negative sign and large magnitude of influence (M8-9). As the competition for resources and economic rents (market share included) has become overwhelming, the importance and necessity of institutionalised innovation capabilities among larger firms have been obscured or, worse off, ignored.

Second, firm size shows mixed results in terms of contribution ROE, with significant and positive effect for M1-4, M8. However, with present of sales growth (SAG) in the equations as IV, size shows negative contribution and is statistically significant, except when growth of firm size (SIG) becomes IV then it shows positive and significant contribution to ROE.

Third, the negative and strongly significant coefficients of sales and growth rate of sales (SAG) found in all estimations suggest that increasing sales appears to dampen both ROE and PMs. This can be explained as an overemphasis of firms on fighting for market shares while lacking opportunities of realising financial values from 'emerging' market opportunities, or even a reflection of the so-called 'destructive creation' in transition (Vuong and Napier, 2014). In this situation, the problem of resource curse, in financial terms, exacerbates the problem of incapability of technological innovation - be it products or processes - and proves to be harmful to corporate financials, making firms plunge into the downward spiral of lower productivity, lack of innovativeness and poorer performance. 
Finally, from the longitudinal data with presence of time effects in the estimation, we can also observe critical periods that have significant impacts on firms' performance (see Figure 4).

Figure 4 Coefficient plot from M4 estimation (see online version for colours)

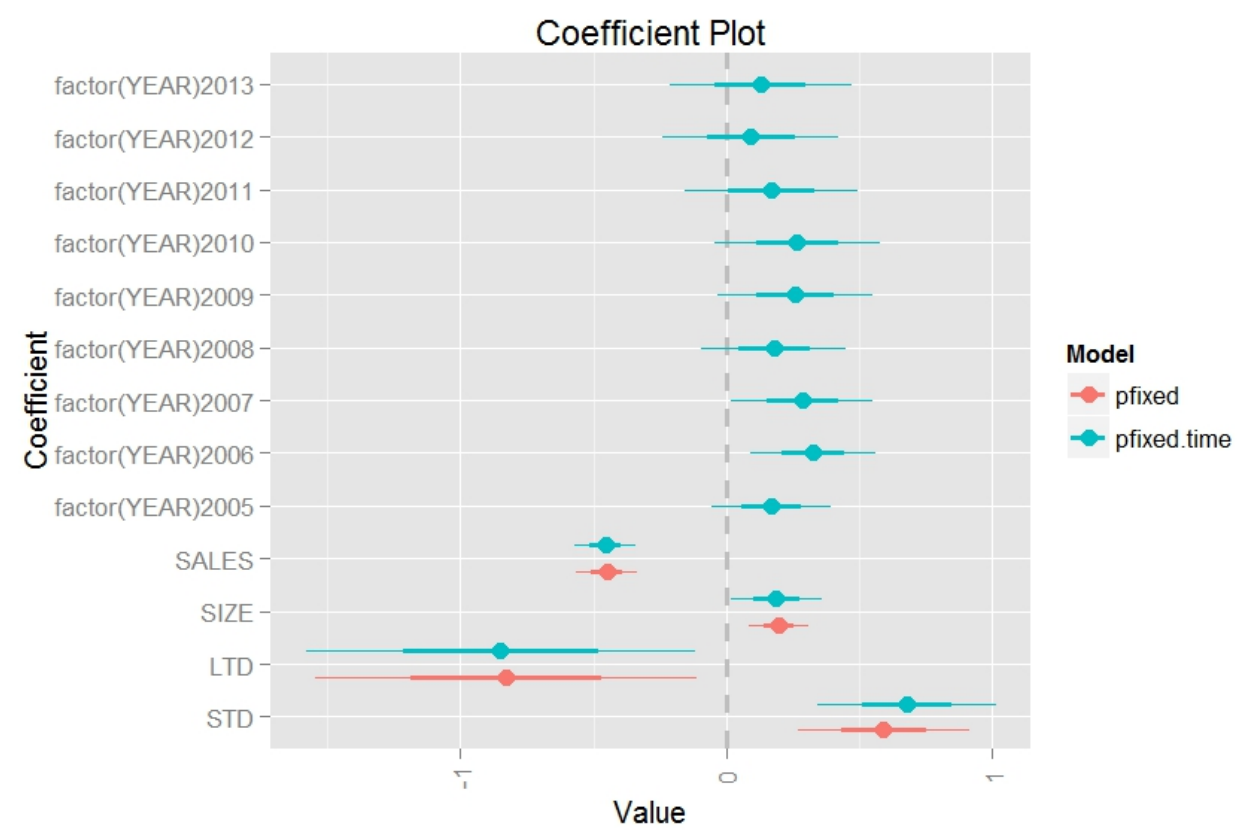

Two subperiods 2006-2007 and 2009-2010 show a substantial and positive influence to firms' ROE in a critical phase of the transition system. Simultaneously, contribution of STD is found significantly stronger when the time effects enter the model. But as the effect has not been rooted in more fundamental strengths of innovation capacity, it died out quickly.

During 2006-2007, Vietnam was entering a boom, with both foreign direct (FDI) and portfolio investments (FPI) surged in anticipation of its forthcoming prosperity following the accession to WTO. It is not surprising if short-term view induced STD, and short-term performance. The next significant period 2009-2010 was when the government of Vietnam followed a rather extreme expansionary monetary policy, injecting a staggering stimulus package of approximately US\$9 billion into the small economy of Vietnam - then its GDP was approximately US\$90 billion GDP. With money flooding the economy, the stock market saw an upsurge, while investors - including listed firms as 'institutional investors' - with quite short-term investments in risky speculative assets, especially equity stocks, reaped huge short-term returns, not uncommonly in the range of $200-300 \%$ over just two years (see Vuong et al., 2014). Illusions about prosperity have obscured the clear vision of productivity, competitiveness and strategic innovation, leading to a typical capital structure skewed toward highly leveraged short-term investments, despite low financial efficiency of core business operations.

To conclude this paper, we may say that empirical evidence from the Vietnamese longitudinal data on listed firms' operational scales (size, sales, and their growth rates), 
sources of finance (short-term versus longer-term debts), and firms' performance has been mixed and still influential altogether. The observed patterns of influence by these predictor variables capture the characteristics of the 'less innovative economy' and 'transition turmoil' period fairly well, unveiling the deeper insights that otherwise observers could only 'feel' rather intuitively. In fact, the results reported in this report support conclusion by Allen (1983) that innovation should be supported by higher wage and lower costs of fund, while the opposite has been observed in Vietnam's emerging economy (Vuong et al., 2016b).

The future direction of research should be taking into account factors relating to technological innovations, which are expected to have joint effect with the factors examined in this study, reflecting deeper insights about the Vietnamese transition system in this particular period of reform (Vuong and Napier, 2015), and perhaps representing a significant shift toward a new socio-cultural and economic paradigm in the near future where the institutionalising of firm's innovativeness will have to play a central role in forming new socio-cultural values in the national economy's innovation system as indicated in Dabic et al. (2016).

\section{Limitations}

This research has a number of limitations. First, although the particular period clearly reflects tumultuous years in transition, only with a longer time span (such as $\mathrm{T}=24-36$ ) can an established shift be confirmed with regard to the factors we have just examined. Second, the picture will become clearer when the results can be compared to those from a select group of most innovative young SMEs - the kind of control that is currently beyond our reach for the time being. And finally, given a short existence of Vietnam stock market, a larger pool of listed firms with $\mathrm{T}>10$ is not possible, therefore looking deeper into sub-groups' characteristics is not possible either.

\section{Acknowledgements}

The author would like to express deep gratitude to Ha Nguyen (FPT University School of Business - FSB) and Dam Thu Ha, Vuong Thu Trang (Vuong \& Associates) for preparing research data; as well as, Nancy K. Napier and Kirk Smith (Boise State University) and Nguyen Pham Muoi (Wall Street Journal) for insightful discussions. Special thanks also go on to Editor Marina Dabic for encouraging the submission, and particularly two anonymous reviewers who have provided excellent opportunities of exchanging ideas for improving the study.

\section{References}

Abor, J. (2005) 'The effect of capital structure on profitability: an empirical analysis of listed firms in Ghana', Journal of Risk Finance, Vol. 6, No. 5, pp.438-445.

ADB (2014) Viet Nam: Financial Sector Assessment, Strategy, and Roadmap, Asian Development Bank, Manila.

ADB (2015) Key Indicators for Asia and the Pacific 2015, Asian Development Bank, Manila. 
Ahmad, Z., Abdullah, N.M.H. and Roslan, S. (2012) 'Capital structure effect on firms performance: focusing on consumers and industrials sectors on Malaysian firms', International Review of Business Research Papers, Vol. 8, No. 5, pp.137-155.

Alipour, M., Mohammadi, M.F.S. and Derakhshan, H. (2015) 'Determinants of capital structure: an empirical study of firms in Iran', International Journal of Law and Management, Vol. 57, No. 1, pp.53-83.

Allen, R.C. (1983) 'Collective invention', Journal of Economic Behavior \& Organization, Vol. 4, No. 1, pp.1-24.

Ang, J.S., Cole, R.A. and Lin, J.W. (2000) 'Agency costs and ownership structure', Journal of Finance, Vol. 55, No. 1, pp.81-106.

Baltagi, B.H. (2005) Econometric Analysis of Panel Data, 3rd ed., John Wiley \& Son, Hoboken, NJ.

Barclay, M.J. and Smith, C.W. (1995) 'The maturity structure of corporate debt', Journal of Finance, Vol. 50, No. 2, pp.609-632.

Beard, D.W. and Dess, G.G. (1981) 'Corporate-level strategy, business-level strategy, and firm performance', Academy of Management Journal, Vol. 24, No. 4, pp.663-688.

Berger, A.N. and di Patti, E.B. (2006) 'Capital structure and firm performance: a new approach to testing agency theory and an application to the banking industry', Journal of Banking and Finance, Vol. 30, No. 4, pp.1065-1102.

Bernstein, S. (2015) 'Does going public affect innovation?', The Journal of Finance, Vol. 70, No. 4, pp.1365-1403.

Bevan, A.A., Estrin, S. and Schaffer, M.E. (1999) 'Determinants of enterprise performance during transition', Paper presented International Conference on Prosperity for the People of Vietnam, London, UK, 8-9 October 1999.

Bottazzi, L. and Da Rin, M. (2002) 'Venture capital in Europe and the financing of innovative companies', Economic Policy, Vol. 17, No. 34, pp.229-270.

Brown, J.R., Fazzari, S.M. and Petersen, B.C. (2009) 'Financing innovation and growth: cash flow, external equity, and the 1990s R\&D boom', The Journal of Finance, Vol. 64, No. 1, pp.151-185.

Capon, N., Farley, J.U. and Hoenig, S. (1990) 'Determinants of financial performance: a meta-analysis', Management Science, Vol. 36, No. 10, pp.1143-1159.

Chakravarthy, B.S. (1986) 'Measuring strategic performance', Strategic Management Journal, Vol. 7, No. 5, pp.437-458.

Champion, D. (1999) 'Finance: the joy of leverage', Harvard Business Review, Vol. 77, No. 4, pp.19-22.

Chang, X., Fu, K., Low, A. and Zhang, W. (2015) 'Non-executive employee stock options and corporate innovation', Journal of Financial Economics, Vol. 115, No. 1, pp.168-188.

Coleman, S. and Robb, A. (2011) 'Capital structure theory and new technology firms: is there a match?', Management Research Review, Vol. 35, No. 2, pp.106-120.

Cosh, A., Cumming, D. and Hughes, A. (2009) 'Outside entrepreneurial capital', The Economic Journal, Vol. 119, No. 540, pp.1494-1533.

Dabic, M., Orac, M. and Daim, T.U. (2016) 'Targeting sustainable competitiveness in Croatia by implementation of '20 Keys' methodology', Journal of Innovation and Entrepreneurship, Vol. 5, No. 10, Art. \#10, DOI: 10.1186/s13731-016-0032-1.

Demsetz, H. and Lehn, K. (1985) 'The structure of corporate ownership: causes and consequences', Journal of Political Economy, Vol. 93, No. 6, pp.1155-1177.

Farber, A. and Vuong, Q.H. (2004) 'New empirical results on anomalies and herd behaviour: Vietnam stock market 2000-2004', Economic Studies, Vol. 44, No. 9, pp.55-59. 
Frees, E.W. (2004) Longitudinal and Panel Data: Analysis and Applications in the Social Sciences, Cambridge University Press, New York, NY.

Gallo, M.A. and Vilaseca, A. (1996) 'Finance in family business', Family Business Review, Vol. 9, No. 4, pp.387-401.

Ghosh, C., Nag, R. and Sirmans, C. (2000) 'The pricing of seasoned equity offerings: evidence from REITs', Real Estate Economics, Vol. 28, No. 3, pp.363-384.

Gleason, K.C., Mathur, L.K. and Mathur, I. (2000) 'The interrelationship between culture, capital structure, and performance: evidence from European retailers', Journal of Business Research, Vol. 50, No. 2, pp.185-191.

Gorton, G. and Rosen, R. (1995) 'Corporate control, portfolio choice, and the decline of banking', Journal of Finance, Vol. 50, No. 5, pp.1377-1420.

GSO (2016) Government Statistics Office of Vietnam [online] http://gso.gov.vn/Default_en.aspx? tabid $=766$ (accessed 15 May 2016).

Hadlock, C.J. and James, C.M. (2002) 'Do banks provide financial slack?', The Journal of Finance, Vol. 57, No. 3, pp.1383-1419.

Hall, B.H. (1992) Investment and Research and Development at the Firm Level: Does the Source of Financing Matter?, No. w4096, National Bureau of Economic Research, Cambridge, Massachusetts MA, USA.

Harris, M. and Raviv, A. (1991) 'The theory of capital structure', Journal of Finance, Vol. 46, No. 1, pp.297-355.

Harvey, C.R., Lins, K.V. and Roper, A.H. (2004) 'The effect of capital structure when expected agency costs are extreme', Journal of Financial Economics, Vol. 74, No. 1, pp.3-30.

Hoffer, C.W. and Sandberg, W.R. (1987) 'Improving new venture performance: some guidelines for success', American Journal of Small Business, Vol. 12, No. 1, pp.11-25.

Hovakimian, A., Hovakimian, G. and Tehranian, H. (2004) 'Determinants of target capital structure: the case of dual debt and equity issues', Journal of Financial Economics, Vol. 71, No. 3, pp.517-540.

Hsiao, C. (2003) Analysis of Panel Data, 2nd ed., Cambridge University Press, New York, NY.

Huang, G. and Song, F.M. (2006) 'The determinants of capital structure: evidence from China', China Economic Review, Vol. 17, No. 1, pp.14-36.

Inkinen, H. (2015) 'Review of empirical research on intellectual capital and firm performance', Journal of Intellectual Capital, Vol. 16, No. 3, pp.518-565.

Iturrioz, C., Aragón, C. and Narvaiza, L. (2015) 'How to foster shared innovation within SMEs' networks: Social capital and the role of intermediaries', European Management Journal, Vol. 33, No. 2, pp.104-115.

Jensen, M.C. and Meckling, W.H. (1976) 'Theory of the firm: managerial behavior, agency costs and ownership structure', Journal of Financial Economics, Vol. 3, No. 4, pp.305-360.

Jordan, J., Lowe, J. and Taylor, P. (1998) 'Strategy and financial policy in UK small firms', Journal of Business Finance \& Accounting, Vol. 25, Nos. 1-2, pp.1-27.

Klingler-Vidra, R. (2014) 'Building a venture capital market in Vietnam: diffusion of a neoliberal market strategy to a socialist state', Asian Studies Review, Vol. 38, No. 4, pp.582-600.

Krishnan, V.S. and Moyer, R.C. (1997) 'Performance, capital structure and home country: an analysis of Asian corporations', Global Finance Journal, Vol. 8, No. 1, pp.129-143.

Lemma, T.T. and Negash, M. (2013) 'Institutional, macroeconomic and firm-specific determinants of capital structure: the African evidence', Management Research Review, Vol. 36, No. 11, pp.1081-1122.

Lungeanu, R., Stern, I. and Zajac, E.J. (2015) 'When do firms change technology-sourcing vehicles? The role of poor innovative performance and financial slack', Strategic Management Journal, Vol. 37, No. 5, pp.855-869. 
Margaritis, D. and Psillaki, M. (2010) 'Capital structure, equity ownership and firm performance', Journal of Banking \& Finance, Vol. 34, No. 3, pp.621-632.

Mehran, H. (1995) 'Executive compensation structure, ownership, and firm performance', Journal of Financial Economics, Vol. 38, pp.163-184.

Modigliani, F. and Miller, M. (1958) 'The cost of capital, corporation finance and the theory of investment', American Economic Review, Vol. 48, No. 3, pp.261-281.

MPI (2016) Ministry of Planning and Investment/National Information System for Business Registration [online] https://dangkykinhdoanh.gov.vn/ (accessed 25 May 2016).

O'Brien, J.P. (2003) 'The capital structure implications of pursuing a strategy of innovation', Strategic Management Journal, Vol. 24, No. 5, pp.415-431.

Ofek, E. (1993) 'Capital structure and firm response to poor performance: an empirical analysis', Journal of Financial Economics, Vol. 34, No. 1, pp.3-30.

Opler, T.C. and Titman, S. (1994) 'Financial distress and corporate performance', The Journal of Finance, Vol. 49, No. 3, pp.1015-1040.

Ozkan, A. (2001) 'Determinants of capital structure and adjustment to long run target: evidence from UK company panel data', Journal of Business Finance \& Accounting, Vol. 28, Nos. 1-2, pp.175-198.

Pahnke, E.C., McDonald, R., Wang, D. and Hallen, B. (2015) 'Exposed: venture capital, competitor ties, and entrepreneurial innovation', Academy of Management Journal, Vol. 58, No. 5, pp.1334-1360.

Pham, T.T.T. and Riedel, J. (2012) 'On the conduct of monetary policy in Vietnam', Asian-Pacific Economic Literature, Vol. 26, No. 1, pp.34-45.

Phung, D.N. and Le, T.P.V. (2013) 'Foreign ownership, capital structure and firm performance: empirical evidence from Vietnamese listed firms', IUP Journal of Corporate Governance, Vol. 12, No. 2, pp.40-52.

Pincus, J. (2015) 'Why doesn't Vietnam grow faster?: State fragmentation and the limits of vent for surplus growth', Journal of Southeast Asian Economies, Vol. 32, No. 1, pp.26-51.

Prahalathan, B. and Ranjani, R.P.C. (2011) 'The impact of capital structure-choice on firm performance: empirical investigation of listed companies in Colombo Stock Exchange, Sri Lanka', International Journal of Research in Commerce and Management, Vol. 2, No. 4, pp.12-16.

Rajan, R.G. and Zingales, L. (1995) 'What do we know about capital structure? Some evidence from international data', The Journal of Finance, Vol. 50, No. 5, pp.1421-1460.

Salteh, H.M., Ghanavati, E., Khanqah, V.T. and Khosroshahi, M.A. (2012) 'Capital structure and firm performance: evidence from Tehran Stock Exchange', International Proceedings of Economics Development \& Research, Vol. 43, No. 1, pp.225-230.

San, O.T. and Heng, T.B. (2011) 'Capital structure and corporate performance of Malaysian construction sector', International Journal of Humanities and Social Science, Vol. 1, No. 2, pp.28-36.

SBV (2016) State Bank of Vietnam's (SBV) Information Portal [online] http://www.sbv.gov.vn/portal/faces/vi/pages/trangchu/tk/hdchtctctd/tlnxttdntd (accessed 15 May 2016).

Schiantarelli, F. and Sembenelli, A. (1999) The Maturity Structure of Debt: Determinants and Effects on Firms' Performance? Evidence from the United Kingdom and Italy, Policy Research Working Paper Series, World Bank.

Stohs, M.H. and Mauer, D.C. (1996) 'The determinants of corporate debt maturity structure', Journal of Business, Vol. 69, No. 3, pp.279-312. 
Thanh, V.T., Cuong, T.T., Dung, B. and Chieu, T.D. (2011) 'Small and medium enterprises access to finance in Vietnam', in Harvey, C., Oum, S. and Narjoko, D.A. (Eds.): Small and Medium Enterprises Access to Finance in Selected East Asian Economies, pp.151-192, Economic Research Institute for ASEAN and East Asia, Jakarta.

Tran, H.T. and Santarelli, E. (2014) 'Capital constraints and the performance of entrepreneurial firms in Vietnam', Industrial and Corporate Change, Vol. 23, No. 3, pp.827-864.

Vuong, Q.H. (2010) Financial Markets in Vietnam's Transition Economy: Facts, Insights, Implications, VDM-Verlag, Saarbrücken, Germany.

Vuong, Q.H. (2014) Vietnam's Political Economy: A Discussion on the 1986-2016 Period, CEB Working Papers Series, $\mathrm{N}^{\circ} 14-010$, Université Libre de Bruxelles, Brussels, Belgium.

Vuong, Q.H. and Napier, N.K. (2014) 'Resource curse or destructive creation in transition: evidence from Vietnam's corporate sector', Management Research Review, Vol. 37, No. 7, pp.642-657.

Vuong, Q.H. and Napier, N.K. (2015) 'Acculturation and global mindsponge: an emerging market perspective', International Journal of Intercultural Relations, Vol. 49, No. 1, pp.354-367.

Vuong, Q.H., Do, T.H. and Vuong, T.T. (2016a) 'Resources, experience and perseverance in entrepreneurs' perceived likelihood of success in an emerging economy', Journal of Innovation and Entrepreneurship, Vol. 5, No. 1, Art. \#18, DOI: 10.1186/s13731-016-0047-7.

Vuong, Q.H., Napier, N.K., Do, T.H. and Vuong, T.T. (2016b) 'Creativity and entrepreneurial efforts in an emerging economy', Business Creativity and the Creative Economy, Vol. 2, No. 1, pp.35-46, DOI: 10.18536/bcce.2016.06.1.1.05.

Vuong, Q.H., Napier, N.K. and Samson, D.E. (2014) 'Relationship between innovations, capital expenditures and post-M\&A performance: evidence from Vietnam, 2005-2012', IUP Journal of Business Strategy, Vol. XI, No. 1, pp.34-41.

WB (2014) Vietnam's Financial Sector Assessment, World Bank/FSAP, World Bank, Washington, DC.

Zeitun, R. and Tian, G.G. (2007) 'Capital structure and corporate performance: evidence from Jordan', Australasian Accounting Business and Finance Journal, Vol. 1, No. 4, pp.40-61. 


\section{Appendix}

\section{A1 Visual presentations of variables by pairs}

Figure A1 (a) LTD and growth of size (b) PM and leverage (LEV) (c) ROE and leverage

(d) ROE and growth of sales (e) ROE and growth of size (f) ROE and short-term debt (g) Log of sales and log of size (h) STD and growth of sales

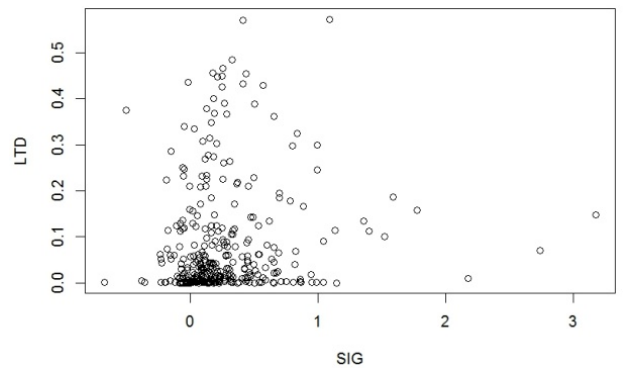

(a)

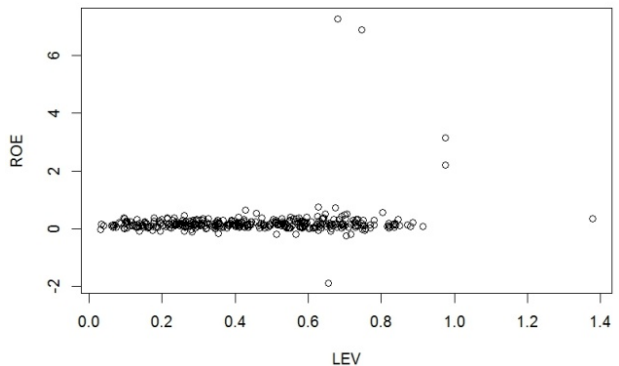

(c)

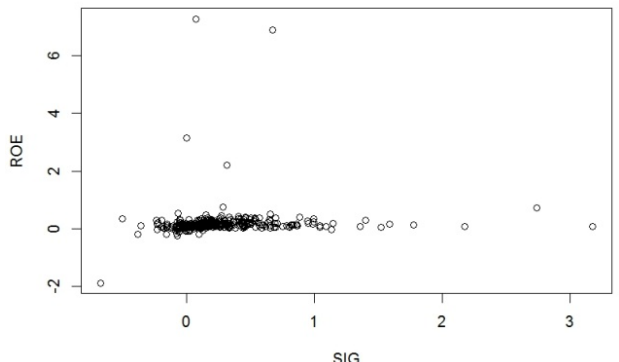

(e)

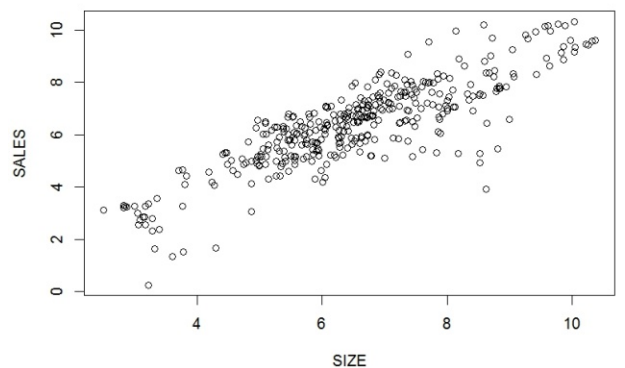

(h)

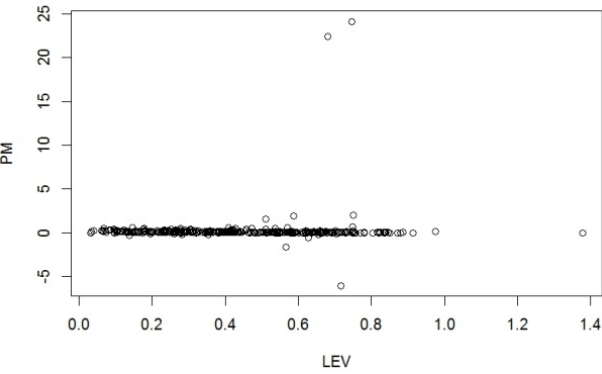

(b)

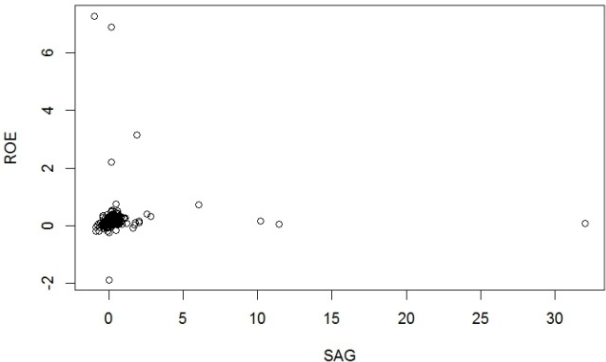

(d)

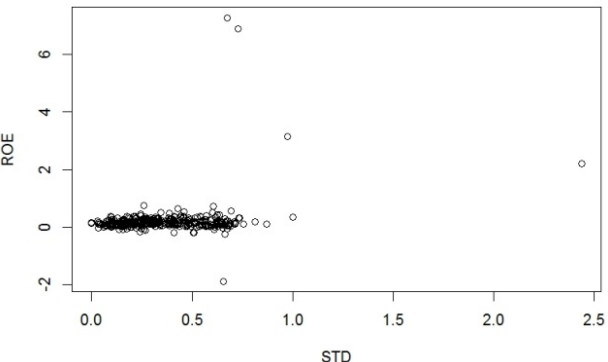

(f)

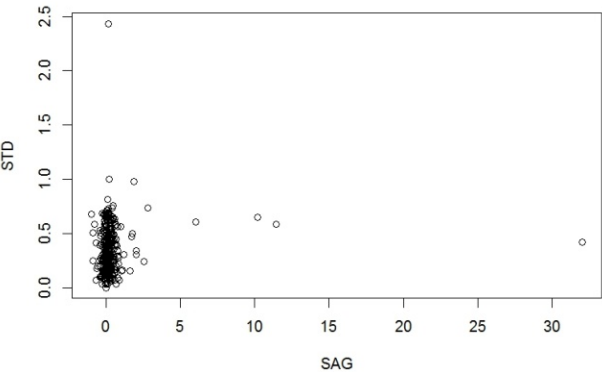

(i) 


\section{A2 Analytical framework for estimations on the data set}

Four models for consideration, with $i=1,2, \ldots N, \mathrm{t}=1,2, \ldots, T$, are given below:

- constant slope coefficients; with intercept varying over individuals

$$
y_{i t}=\alpha_{i}^{*}+\sum_{k=0}^{K} \beta_{k} x_{k i t}+u_{i t}
$$

- constant slope coefficients; intercept varying over individuals and time

$$
y_{i t}=\alpha_{i t}^{*}+\sum_{k=0}^{K} \beta_{k} x_{k i t}+u_{i t}
$$

- all coefficients vary over individuals

$$
y_{i t}=\alpha_{i}^{*}+\sum_{k=0}^{K} \beta_{k i} x_{k i t}+u_{i t}
$$

- all coefficients vary over individuals and time

$$
y_{i t}=\alpha_{i t}^{*}+\sum_{k=0}^{K} \beta_{k i t} x_{k i t}+u_{i t}
$$

Equation (1) and equation (2) are widely used for analysing this type of data. To assess the effects of both quantitative and qualitative factors, the general linear model has the form:

$$
y_{i t}=\alpha_{i t}^{*}+\beta_{i t}^{\prime} \mathrm{x}_{i t}+u_{i t},
$$

where $\alpha_{i t}^{*}$ and $\beta_{i t}^{\prime}=\left(\beta_{1 i t}, \beta_{2 i t}, \ldots, \beta_{K i t}\right)$ are $1 \times 1$ and $1 \times K$ vectors of constants that vary across $\mathrm{i}$ and $\mathrm{t} ; \mathrm{x}_{i t}^{\prime}=\left(x_{1 i t}, x_{2 i t}, \ldots, x_{K i t}\right)$ is a $1 \times K$ vector of exogenous variables; $u_{i t}$ the error term. The estimations are to examine if:

1 both slopes and intercepts simultaneously are homogenous among different individuals at different times

2 only regression slopes homogenous

3 only intercepts are homogenous.

\section{Fixed effects (FE) model}

Due to the possibility of varying impacts of IV over the years, the FE analysis is expected to capture the relationship between predictor and outcome variables within an entity, by removing the effect of the time-invariant characteristics from predictor variables to gauge predictor variables' net effects. Eq.6 represents a specification which removes time-specific effects, and is focused on individual-specific effects:

$$
y_{i t}=\alpha_{i}^{*}+\beta^{\prime} \mathrm{x}_{i t}+u_{i t},
$$


where $u_{i t}$ is uncorrelated with $\left(\mathrm{x}_{i 1}, \ldots, \mathrm{x}_{i T}\right)$ and $u_{i t} \sim$ i.i.d. $\left(0, \sigma_{u}^{2}\right)$. In this model of analysis, effects of omitted individual-specific variables $\left(\alpha_{i}\right)$ are treated as fixed constants over time. According to Hsiao (2003), as $E \mathrm{u}_{i}=0 E \mathrm{u}_{i} \mathrm{u}_{i}^{\prime}=\sigma_{u}^{2} I_{T}, E \mathrm{u}_{i} \mathrm{u}_{j}^{\prime}=0$, if $i \neq j, I_{T}$ is the $T$ $\times T$ identity matrix, the OLS estimator for equation (6) is the best linear unbiased estimator:

$$
\hat{\alpha}_{i}^{*}=\bar{y}_{i}-\beta^{\prime} \bar{x}_{i},
$$

where

$$
\begin{aligned}
& \bar{y}_{i}=\frac{1}{T} \sum_{i=1}^{T} y_{i t}, \overline{\mathrm{x}}_{i}=\frac{1}{T} \sum_{i=1}^{T} \mathrm{x}_{i t} . \\
& \hat{\beta}_{C V}=\left[\sum_{i=1}^{N} \sum_{t=1}^{T}\left(\mathrm{x}_{i t}-\overline{\mathrm{x}}_{i}\right)\left(\mathrm{x}_{i t}-\overline{\mathrm{x}}_{i}\right)^{\prime}\right]\left[\sum_{i=1}^{N} \sum_{t=1}^{T}\left(\mathrm{x}_{i t}-\overline{\mathrm{x}}_{i}\right)\left(y_{i t}-\bar{y}_{i}\right)^{\prime}\right]
\end{aligned}
$$

Equation (6a) can also take the form equation (6b) with both $\mu$ and $\alpha_{i}$ being fixed constants. Imposing the restriction $\sum_{i=1}^{N} \alpha_{i}=0$ helps solve for constants, in which case the individual effect $\alpha_{i}$ represents the deviation of the $\mathrm{i}^{\text {th }}$ individual from the common mean intercept, $\mu$.

$$
y_{i t}=\mu+\beta^{\prime} \mathrm{x}_{i t}+\alpha_{i}+u_{i t},
$$

Equation (6b) can be rewritten in a more familiar specification of 6(c) as follows:

$$
y_{i t}=\beta_{0}+\beta_{1} x_{1, i t}+\cdots+\beta_{K} x_{K, i t}+\gamma_{2} E_{2}+\cdots+\gamma_{n} E_{n}+u_{i t},
$$

where $y_{i t}$ is the DV corresponding to individual $(i)$ and time $(t) ; \beta_{k}$ the coefficient for the corresponding IV; $x_{k, i t}$ the IV; $\gamma_{n}$ coefficient for the binary regressor; and $E_{n}$ the entity/individual $n$. With time entering the estimations as regressors, a time and entity FEs specification is given in (6d):

$$
y_{i t}=\beta_{0}+\beta_{1} x_{1, i t}+\cdots+\beta_{K} x_{K, i t}+\gamma_{2} E_{2}+\cdots+\gamma_{n} E_{n}+\delta_{2} T_{2}+\cdots+\delta_{t} T_{t}+u_{i t},
$$

where $T_{t}$ are binary/dummy variables, with corresponding coefficients $\delta_{t}$.

\section{RE model}

The rationale behind the use of a REs model is that their unobserved individual effects consist of elements that are random and uncorrelated with the predictor variables. In this analysis, individual-specific effects are treated as random variables, thus the residual $v_{i t}$ consists of three components as in equation (7a):

$$
v_{i t}=\alpha_{t}+\lambda_{t}+u_{i t},
$$

where

$$
E \alpha_{i}=E \lambda_{t}=E u_{i t}=0, E \alpha_{i} \lambda_{t}=E \lambda_{t} u_{i t}=E \alpha_{i} u_{i t}=0,
$$




$$
\begin{aligned}
& E \alpha_{i} \alpha_{j}=\left\{\begin{array}{ccc}
\sigma_{\alpha}^{2} & \text { if } & i=j \\
0 & \text { if } & i \neq j
\end{array}\right. \\
& E \lambda_{t} \lambda_{s}=\left\{\begin{array}{ccc}
\sigma_{\lambda}^{2} & \text { if } & t=s \\
0 & \text { if } & t \neq s
\end{array}\right. \\
& E u_{i t} u_{j s}=\left\{\begin{array}{lll}
\sigma_{u}^{2} & \text { if } & i=j, t=s \\
0 & \text { otherwise }
\end{array}\right.
\end{aligned}
$$

and

$$
E \alpha_{i} \mathrm{x}_{i t}^{\prime}=E \lambda_{t} \mathrm{x}_{i t}^{\prime}=E u_{i t} \mathrm{x}_{i t}^{\prime}=0^{\prime} .
$$

The variance of $y_{i t}$ conditional on $\mathrm{x}_{i t}$ is:

$$
\sigma_{y}^{2}=\sigma_{\alpha}^{2}+\sigma_{\lambda}^{2}+\sigma_{u}^{2}
$$

The widely used functional forms for estimation is given in (7b):

$$
y_{i t}=\beta_{0}+\beta_{1} x_{1, i t}+\cdots+\beta_{K} x_{K, i t}+\gamma_{2} E_{2}+\cdots+\gamma_{n} E_{n}+u_{i t}+\varepsilon_{i t},
$$

where $u_{i t}$ represents 'between-entity' error term; and, $\varepsilon_{i t}$ 'within-entity' error.

For a full account of technical treatments for longitudinal and panel data analysis, see Hsiao (2003) and Frees (2004). 